\title{
Study of the Electrochemiluminescence Based on the Reaction of Hydroxyl Compounds with Ruthenium Complex
}

\author{
Xi Chen, Li Jia, Xiaoru Wang and Guanglin Hu \\ Research Lab of SEDC of Analytical Science for Material and Life, Department of Chemistry, Xiamen \\ University, Xiamen, Fujian 361005, China
}

Masanori Sato

Lab of Analytical Chemistry, Kyoto Institute of Technology, Kyoto 606, Japan

The electrochemiluminescence (ECL) phenomena of some hydroxyl compounds in the presence of tris $(2,2$ 'bipyridyl) ruthenium(III) $\left[\mathrm{Ru}(\mathrm{bpy})_{3}{ }^{2+}\right]$ have been found. The experiments were performed in a flow injection system equipped with a thin-layer electrolysis cell. A three-electrode system with a working electrode of a glassy carbon disk $\left(22.1 \mathrm{~mm}^{2}\right)$, was used for potentiosatic control of the electrolytic system. The ECL behaviors of sucrose, fructose, glucose, mannose, glycerol, ascorbic acid, citric acid, tartaric acid, some monohydric alcohols and polyhydric alcohols, have been discussed. The ECL reaction mechanisms of these compounds and $\mathrm{Ru}(\mathrm{bpy})_{3}{ }^{2+}$ were also discussed.

Keywords Electrochemiluminescence, tris(2,2'-bipyridyl)ruthenium(II), hydroxyl compounds, HPLC

Electrochemiluminescence (ECL) arises from an energetic electron-transfer reaction between electrogenerated radical ions, to form an excited state that emits in the visible region. More recently, ECL is achieved by the simultaneous oxidation of tris $\left(2,2^{\prime}-\right.$ bipyridyl)ruthenium(II) $\left[\mathrm{Ru}(\mathrm{bpy})_{3}{ }^{2+}\right]$ and some coreactants, such as hydrazine', oxalate ${ }^{2}$, peroxydisulfate ${ }^{3}$, aliphatic amines ${ }^{4}$, amino acids $^{5.7}$ and ascorbic acid. ${ }^{8}$ In general the ECL of $\mathrm{Ru}(\mathrm{bpy})_{3}{ }^{2+}$ results from the reaction of $R u(b p y){ }_{3}{ }^{3+}$ with reductants to give $\mathrm{Ru}(\mathrm{bpy})_{3}{ }^{2+}$ * as follows:

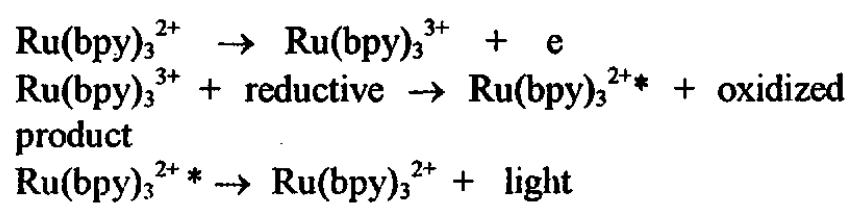

In the course of the ECL study, we found that bright emission was produced in the reaction of $\mathrm{Ru}(\mathrm{bpy})_{3}{ }^{3+}$ and some compounds with hydroxyl group such as sucrose, fructose, glucose, mannose, D-gluconic acid, citric acid, tartaric acid, monohydric acholos and polyhydric alchols. In this report, we describe the mechanisms of $\mathrm{Ru}(\mathrm{bpy})_{3}{ }^{3+}$ ECL reaction with these compounds.

\section{Experimental}

\section{Apparatus}

The luminescence intensity was observed by modifying a commercially available chemiluminescence analyzer (S-3400, Soma Kogaku, Tokyo, Japan). A thin layer electrolysis cell for ECL observation was designed in our laboratory. The main body of the cell was composed of two pieces of Diflon block tightly fixed to each other. Since luminescence intensity is closely related with the orifice shape and thickness of the Teflon spacer inside the cell, a spacer sheet with a thickness of $\mathbf{5 0}$ $\mu \mathrm{m}$ was chosen. The volume of the thin layer cell 
was $1.5 \mu$ l. The experimental setup is shown in Figure 1. A three-electrode system was used for potentiostatic control of the electrolytic system. The working electrode was a glassy carbon disk (GC, $22.1 \mathrm{~mm}^{2}$ ). The counter electrode set at the outlet consisted of a stainless-steel pipe, and the reference electrode was $\mathrm{Ag} / \mathrm{AgCl}$. A potentiostat (Princeton Appl. Res., type 174A, USA) was used for electrolysis.

HPLC was performanced using a LC-6A (Simadzu, Japan) liquid chromatography equipped with a Rheohyne 7125 sample injector (Cotai, CA, USA, 20 $\mu 1)$. An ion exchange column (Merck poly-spher OA$\mathrm{HY}, 300 \times 6.5 \mathrm{~mm} \mathrm{I}$. D) was used for the analysis of electrooxidation products of $\mathrm{D}$-gluconic acid, sucrose, fructose, glucose, mannose and tartaric acid. After the electrolysis, $20 \mu \mathrm{l}$ solution were neutralized and then analyzed by HPLC. Identification of oxalate was achieved by comparing its retention time with that of known standard. The mobile and experimental parameters were selected as Fischer reports. ${ }^{9}$ The reagent solution was prepared by dissolving $1.0 \mathrm{mM}$ $\mathrm{Ru}(\mathrm{bpy})_{3}{ }^{{ }^{+}}$in $0.1 \mathrm{M} \mathrm{KOH}$. All the electrochemical measurements were carried out at room temperature, a GC electrode with the size of $3 \times 3 \times 0.2 \mathrm{~cm}(\mathrm{~W} \times \mathrm{L}$ $\times \mathrm{H}$ ) was used for the electrolysis of D-gluconic acid, sucrose, fructose, glucose, mannose and tartaric acid. Another GC disc electrode $\left(22.1 \mathrm{~mm}^{2}\right)$ was contributed for cyclic voltammetric (CV) experiments. $\mathrm{CV}$ experiments and luminescence spectra were finished in s batch system. Before each experiment, the solutions were departed with ultrapure nitrogen. $\mathrm{Ag} / \mathrm{AgCl}(1 \mathrm{M} \mathrm{LiCl})$ was severed as reference for all potential measurements.

\section{Chemicals and solution}

$\mathrm{Ru}(\mathrm{bpy})_{3} \mathrm{Cl}_{2} \cdot 6 \mathrm{H}_{2} \mathrm{O}$ was purchased from Sigma Chemical Co. ( St. Louis, MO, USA) and was used without further purification. D-gluconic acid and tartronic were from Nakalai Tesque. Inc. (Kyoto, Japan), ascorbic acid, oxalic acid, citric acid and saccharic acid were obtained from Wako Pure Chemical Industries, Ltd. (Osaka, Japan), sucrose, fructose, glucose, mannose glycerol, malic acid and tartaric acid were purchased from Aldrich Chemical company, Inc. (Milwakee, WI, USA). All the other chemicals were of guaranteed grade. Twice-distilled deionized water was used throughout.

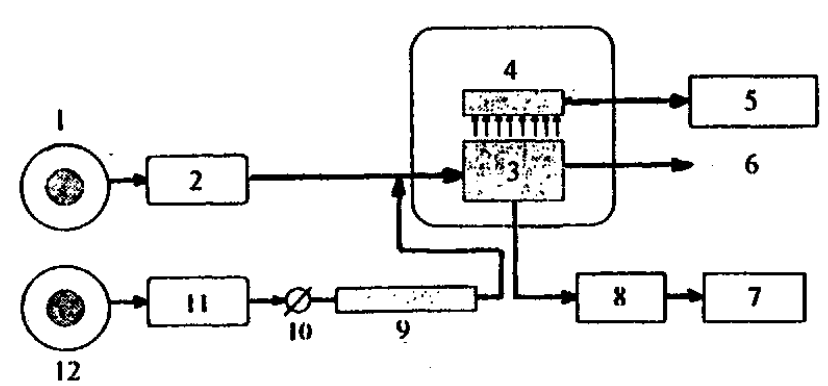

Fig. 1 Experimental setup for ECL-HPLC.

1. reagent reservoir; 2 . pump; 3 . ECL cell; 4. photomultiplier tube; 5. recorder (luminescence intensity); 6. drain; 7. recorder (current); 8. potentiostat; 9. column; 10. injector. 11. pimp; 12. eluent reservoir.

\section{Result and Discussion}

Cyclic voltammetry (CV) of electrolyzed D-gluconic acid and monohydric alcohols

An irreversible anodic wave at sbout $+0.50 \mathrm{~V}$ for oxalic acid could be attributed to oxidation of $\mathrm{C}_{2} \mathrm{O}_{4}{ }^{2-}$ to $\mathrm{CO}_{2}{ }^{-0}$, This wave shifted to positive potential with the increase of solution $\mathrm{pH}$. Corresponding to the oxidation potential of oxalic acid, a clear oxidation of D-gluconic acid at $+0.5 \mathrm{~V}$ could be identified after it was electrolyzed for 30 minutes at the potential of $+1.20 \mathrm{~V}$. The oxidized current peak could also be found after the compounds, such as sucrose, fructose, glucose, mannose, glycerol, tartaric acid and ascorbic acid, were electrolyzed.

$\mathrm{Kokoh}^{10}$ reported that oxidation of D-gluconic acid using a triple-pulse potential on a platinum electrode, the product rate of oxalic acid was about $18 \%$ after electrolysis for 10 hours. Figure 2 presents a typical chromatogram of the electrooxidation products of D-gluconic acid in 0.1 M KOH solution. $2 \mathrm{mM} \mathrm{D-gluconic} \mathrm{acid} \mathrm{was}$ electrolysed for 60 mintues, and neutralized to about $\mathrm{pH} 7.0$ with $\mathrm{H}_{2} \mathrm{SO}_{4} .20 \mu$ l of this solution was then chromatographed and detected. The concentration of the reaction product, oxalic acid, increased with the increasing of $\mathrm{pH}$ and electrolysis time. Analysis of the electrooxidation products of D-gluconic acid indicated that oxalic acid was produced in $0.1 \mathrm{M}$ 
$\mathrm{KOH}$ on a glassy carbon electrode at the potential of $+1.35 \mathrm{~V}$ (vs. $\mathrm{Ag} / \mathrm{AgCl}$ ), and its product rate was about $11 \%$ under the experimental condictions shown in Figure 2. Using this analysis method, oxalic acid could also be indentified in the products of the oxidation of sucrose, fructose, glucose, mannose and tartaric acid.

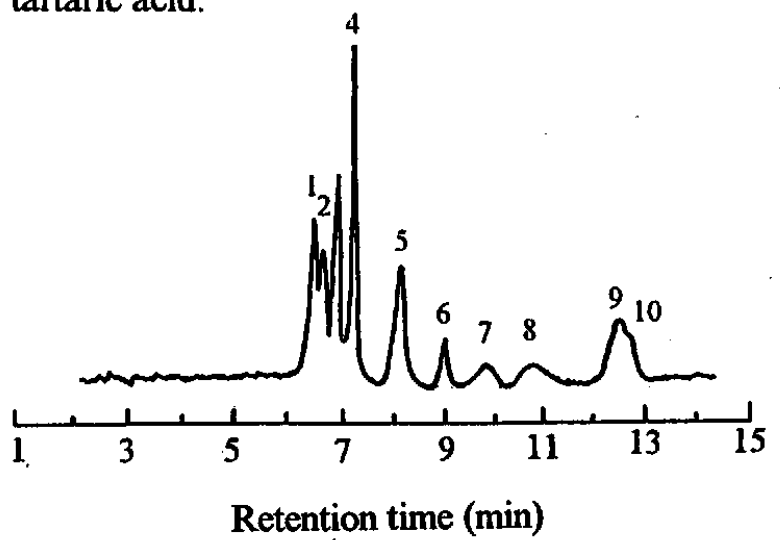

Fig. 2 Typical chromatogram for electrolyzed Dgluconic acid.

1, oxalic acid; 2, 2-keto-D-gluconic acid; 3, 5keto-D-gluconic acid; 4, gluconic acid; 5, tartaric acid; 6, glyceric acid; 7, unknown; 8, unknown; 9, glucaric acid; 10, formic acid.

Conditions: Merck OA-HY column; room temperature; flow rate $0.5 \mathrm{ml} / \mathrm{min}$; eluent, $0.01 \mathrm{~N}$ $\mathrm{H}_{2} \mathrm{SO}$; $\mathrm{UV}$ detection at $210 \mathrm{~nm}$; injection volume, 20 . $\mu \mathrm{l}$; electrolysis time, $60 \mathrm{~min}$.

The mechanism of ECL from $\mathrm{Ru}(\mathrm{bpy})_{3}{ }^{2+} / \mathrm{C}_{2} \mathrm{O}_{4}{ }^{2-}$ system at a platinum or carbon electrode has been studied by Bard. ${ }^{11,12}$ First $\mathrm{Ru}(\mathrm{bpy})_{3}{ }^{{ }^{+}}$was oxidized at the electrode.

$\mathrm{Ru}(\mathrm{bpy})_{3}{ }^{2^{+}} \rightarrow \mathrm{Ru}(\mathrm{bpy})_{3}{ }^{3^{+}}+\mathrm{e}$

$\mathrm{C}_{2} \mathrm{O}_{4}{ }^{2-}$ was also oxidized in the diffusion layer near the electrode surface.

$\mathrm{C}_{2} \mathrm{O}_{4}{ }^{2-} \rightarrow \mathrm{C}_{2} \mathrm{O}_{4}{ }^{--}+\mathrm{e}$

$\mathrm{Ru}(\mathrm{bpy})_{3}{ }^{{ }^{+}}+\mathrm{C}_{2} \mathrm{O}_{4}{ }^{{ }^{-}-} \rightarrow \mathrm{Ru}(\mathrm{bpy})_{3}{ }^{{ }^{++}}+\mathrm{C}_{2} \mathrm{O}_{4}{ }^{{ }^{--}}$

$\mathrm{C}_{2} \mathrm{O}_{4}{ }^{--} \rightarrow \mathrm{CO}_{2}+\mathrm{CO}_{2}{ }^{\circ-}$

The intermediated radical anion, $\mathrm{CO}_{2}{ }^{\circ-}$, reacted with to produce the excited state, $\mathrm{Ru}(\mathrm{bpy})_{3}{ }^{{ }^{+*}}$.

$\mathrm{Ru}(\mathrm{bpy})_{3}{ }^{{ }^{+}}+\mathrm{CO}_{2}{ }^{--} \rightarrow \mathrm{Ru}(\mathrm{bpy})_{3}{ }^{{ }^{+*}}+\mathrm{CO}_{2}$

$\mathrm{Ru}(\mathrm{bpy})_{3}{ }^{2+}+\mathrm{CO}_{2}{ }^{--} \rightarrow \mathrm{Ru}(\mathrm{bpy})_{3}{ }^{+}+\mathrm{CO}_{2}$

$\mathrm{Ru}(\mathrm{bpy})_{3}{ }^{+}+\mathrm{Ru}(\mathrm{bpy})_{3}{ }^{{ }^{+}} \rightarrow \mathrm{Ru}(\mathrm{bpy})_{3}{ }^{2^{+*}}$
$\mathrm{Ru}(\mathrm{bpy})_{3}{ }^{2^{+^{*}}} \rightarrow \mathrm{Ru}(\mathrm{bpy})_{3}{ }^{2^{+}}+\mathrm{hv}(\lambda=610 \mathrm{~nm})$

The same luminescence wavelength of D-gluconic acid, sucrose, fructose, glucose, mannose and tartaric acid with $\mathrm{Ru}(\mathrm{bpy})_{3}{ }^{{ }^{+}}$at $608 \mathrm{~nm}$ confirmed that the luminescences from the reaction of these compound at the potential of $+1.35 \mathrm{~V}$, are all caused by the production of oxalic acid.

The result of CV experiments and ECL intensity comparison of some monohydric alcohols are presented in Table 1. Clearly, the anodic potentials of monohydric alcohols became less positive with increasing alkyl chain length of the molecule, and corresponding, the ECL intensity decreased reversibly. The studies of some aliphatic alcohols oxidation on a platinum electrode in non-aqueous solution showed that the oxidized products involved alkoxide radicals [ $\left(\mathrm{RCH}_{2} \mathrm{O}^{\circ}\right), \mathbf{R}=\mathbf{H}\left(\mathrm{CH}_{2}\right) \mathbf{n}, \mathbf{n}=\mathbf{0} \sim$ 5] at a lower electrolytic potential first, and then aldehyde ion $\left(\mathrm{RCHO}^{-}\right)$, the last stage included carboxylic ion ( $\mathrm{RCOO}^{-}$) at more positive electrolytic potential. ${ }^{13,14}$ Recently, Hitmi ${ }^{15}$ analyzed the product in the oxidation of ethanol. When applied potential was lower than $0.8 \mathrm{~V} / \mathrm{rhe}$, the major product of the oxidation of ethanol was acetaldehyde, the oxidation could directly be acetic acid when the potential was over $0.8 \mathrm{~V} / \mathrm{rhe}$. The products of the exctrooxidation of $\mathrm{CH}_{3} \mathrm{OH}$ in alkaline media were suggested to be $\mathrm{HCHO}$ and $\mathrm{HCOOH}^{16}$ Karatani $^{17}$ reported the molar ratio of $\mathrm{HCOO}^{-}$to $\mathrm{HCHO}$ was about 85:15 at the potential of $+1.3 \mathrm{~V}$ (vs. $\mathrm{Ag} / \mathrm{AgCl}$ ), and it increased with the potential in alkaline solution.

The obtained anodic waves of monohydric alcohols are favor to that the anodic current at approximately $+1.28 \mathrm{~V}$ to $+1.48 \mathrm{~V}$ are triggered by the electrolytic oxidation of monohydric alchols to alkoxide radicals and carboxylic ions in alkaline solution.

As for our ECL system, a mechanism for the reaction of $\mathrm{Ru}(\mathrm{bpy})_{3}{ }^{2+}$ with the monohydric alcohols is proposed in Scheme 1. It is based the fact the alkoxide radicals were produced first step in the alkaline solution ${ }^{17}$ and then oxidized to carboxylic ions further at the potential about $+1.30 \mathrm{~V}$, the electronically excitcd states of aldehydes could be produced. $\mathrm{Ru}(\mathrm{bpy})_{3}{ }^{2+}$ was also oxidized to $\mathrm{Ru}(\mathrm{bpy})_{3}{ }^{3+}$ at the applied potential. The reaction result between alkoxide radicals and $\mathrm{Ru}(\mathrm{bpy}){ }_{3}{ }^{3+}$ was 
Table 1 Comparison of oxidation potential and relative ECL intensity for monohydric alcohol

\begin{tabular}{llllllll}
\hline Compound & Pox $(\mathrm{V})$ & $\mathrm{P}_{\mathrm{ECL}}(\mathrm{V})$ & $\mathrm{ip}(\mathrm{mA})$ & $\mathrm{I}_{\mathrm{ECL}}{ }^{*}(\mathrm{mV})$ & $\lambda(\mathrm{nm})^{* * *}$ & $\mathrm{I}_{\mathrm{ECL}}{ }^{\mathrm{RU} * *}(\mathrm{mV})$ & $\lambda(\mathrm{nm})^{* *}$ \\
\hline Methanol & +1.28 & +1.52 & 1.25 & 22 & 545 & 256 & 608 \\
Ethanol & +1.31 & +1.58 & 1.21 & 18 & 550 & 239 & 609 \\
1-Propanol & +1.34 & +1.60 & 1.00 & 15 & 558 & 235 & 608 \\
1-Butanol & +1.40 & +1.61 & 0.40 & 8 & 572 & 201 & 609 \\
1-Pentanol & +1.45 & +1.60 & 0.12 & 3 & -- & 122 & 608 \\
1-Hexanol & +1.48 & +1.65 & 0.10 & 1 & -- & 65 & 608 \\
\hline
\end{tabular}

* In $0.2 \mathrm{M} \mathrm{KCl}-\mathrm{KOH}$ solution, $\mathrm{pH} 12.0$, concentration of each alcohol: $0.1 \mathrm{M}$, applied potential: $+1.50 \mathrm{~V}$.

** In $0.2 \mathrm{M} \mathrm{KCl}-\mathrm{KOH}$ solution, $0.05 \mathrm{mM} \mathrm{Ru}(\mathrm{bpy})_{3}{ }^{2+}, \mathrm{pH} 12.0$, concentration of each alcohol: $10 \mathrm{mM}$, applied potential: $+1.65 \mathrm{~V}(\mathrm{AgCl} / \mathrm{Ag})$.

*** In $0.2 \mathrm{M} \mathrm{KCl}-\mathrm{KOH}$ solution, $\mathrm{pH} 12.0$, concentration of each alcohol: $1.0 \mathrm{M}$, applied potential: $+1.50 \mathrm{~V}$.

to yield excited state $\mathrm{Ru}(\mathrm{bpy})_{3}{ }^{2+*}$. ECL could not be obtained at lower applied potential because the oxidation of $\mathrm{Ru}(\mathrm{bpy})_{3}{ }^{2+}$ was necessary. The ECL emission spectra of $R u(b p y)_{3}{ }^{2+}$ and of a mixture of $\mathrm{Ru}(\mathrm{bpy})_{3}{ }^{2+}$ with monohydric alcohols (Tab. 1) can confirm this conclusion further.

$\mathrm{Ru}(\mathrm{bpy})_{3}{ }^{2+} \rightarrow \mathrm{Ru}(\mathrm{bpy})_{3}{ }^{3+}+\mathrm{e}$

$\mathrm{RCH}_{2} \mathrm{OH}+\mathrm{OH}^{-} \rightarrow \mathrm{RCH}_{2} \mathrm{O}^{-}+\mathrm{H}_{2} \mathrm{O}$

$\mathrm{RCH}_{2} \mathrm{O}^{-} \rightarrow \mathrm{RC}_{2} \mathrm{O}^{-}+\mathrm{e}$

$\mathrm{RCH}_{2} \mathrm{O}^{-}+\mathrm{OH}^{-} \rightarrow \mathrm{RCHO}^{-}+\mathrm{H}_{2} \mathrm{O}$

$2 \mathrm{RCH}_{2} \mathrm{O}^{-} \rightarrow \mathrm{RCHO}^{*}+\mathrm{RCH}_{2} \mathrm{OH}$

$\mathrm{RCHO}^{-}+3 \mathrm{OH}^{-} \rightarrow \mathrm{RCOO}^{-}+2 \mathrm{H}_{2} \mathrm{O}+3 \mathrm{e}$

$4 \mathrm{OH}^{-}+\mathrm{RCH}_{2} \mathrm{O}^{-}+3 \mathrm{Ru}(\mathrm{bpy})_{3}{ }^{3+} \rightarrow \mathrm{RCOO}^{-}+$ $\mathrm{Ru}(\mathrm{bpy})_{3}{ }^{2+*}+3 \mathrm{H}_{2} \mathrm{O}$

$\mathrm{Ru}(\mathrm{bpy})_{3}{ }^{2+*} \rightarrow \mathrm{Ru}(\mathrm{bpy})_{3}{ }^{2+}+$ light $(\lambda=608 \mathrm{~nm})$

Scheme 1. The ECL reaction sequence of monohydric alcohols and $\mathrm{Ru}(\mathrm{bpy})_{3}{ }^{2+}$.

\section{Comparison of ECL intensities for polyhydric alcohols}

It is of interest to compare the ECL intensities of polyhydric alcohols. As shown in Table 2, a fact was observed that the ECL intensity increased with the numbers of hydroxyl groups increased. In addition, the polytydric alcogols bearing several adjacent alcoholic hydroxyl groups were weaker light emission than those bearing non-adjacent alcoholic hydroxyl groups. These were due to fact that the self-inhibition among the neighboring oxidized and remained unoxidized alcoholic hydroxyl groups because alcoholic hydroxyl groups usually act as radical scavengers. ${ }^{18}$ These results take further step to indicate the radical intermediates were generated in the luminescence reaction of alcohols and $\mathrm{Ru}(\mathrm{bpy})_{3}{ }^{2+}$.

Table 2 Comparison of ECL intensity for polyhydric alcohols

\begin{tabular}{lc}
\hline Compound & Luminescence intensity (mV) \\
\hline 1,2-propanediol & 293 \\
1,3-propanediol & 268 \\
1,2,3-propanetriol & 599 \\
1,2-butanediol & 322 \\
2,3-butanediol & 240 \\
1,4-butanediol & 263 \\
1,2-ethanediol & 528 \\
erythritol & 379 \\
adonitol & 681 \\
D-glucitol & 723 \\
\hline
\end{tabular}

Concentration of each polyhydric alcohol: $10 \mathrm{mM}$.

In conclusion, the ECL reaction process of polyhydric alcohols and $\mathrm{Ru}(\mathrm{bpy})_{3}{ }^{2+}$ is different from monohydric alcohols. The investigations showed that the ECL between $\mathrm{Ru}(\mathrm{bpy})_{3}{ }^{2+}$ and oxidized polyhydric alcohols or orgainic acids with hydroxyl group was caused the reaction oxalate and $\mathrm{Ru}(\mathrm{bpy}){ }_{3}{ }^{3+}$ in alkaline soultion. the produce of the reducing intermediates, alkoxide radical ions, takes an important role in the luminescence of monohydric alcohols and $\mathrm{Ru}(\mathrm{bpy})_{3}{ }^{2+}$. The brighter emssion yielded for the less alkyl chain length as their less negative oxidized potentials among the monohydric 
alcohols. In addition, the polyhydric alcohols with more numbers of hydroxyl groups had brighter emission, but those bearing adjacent alcoholic hydroxyl groups yielded weaker luminescence.

\section{Acknowledgments}

The authors would like to express our thanks to the Japanese Ministry of Education, Science and Culture for their donation. We are also grateful to Chinese Postdoctoral Foundation for their support of this research.

\section{References}

1. W. K. Nonidez and D. E. Leyden, Anal. Chim. Acta, 96, 401(1978).

2. I. Rubinstein, C. R. Martin and A. J. Bard, Anal. Chem., 55, 1580 (1983).

3. D. Ege, W. G. Becker and A. J. Bard, Anal. Chem., 56, 2413(1984).

4. J. B. Noffsinger and N. D. Danielson, Anal. Chem., 59, 865(1987).

5. H. Li, K. A. Cox and N. D. Danielson, Anal. Lett., 23, 195(1990).
6. W. A. Jackson and D. R. Bobbitt, Anal. Chim. Acta, 285, 309(1994).

7. W. Y. Lee and T. A. Nieman, J. Chromatog. A, 659, 111(1994).

8. X. Chen and M. Sato, Anal. Sci., 11, 749(1995).

9. K. Fischer, H. P. Bipp, D. Bienieck and A. Kettrup, J. Chromatogr. A, 706, 361 (1995).

10. K. B. Kokoh, P. Parpot, E. M. Belgsir, J. M. Leger, B. Beden and C. Camy, Electrochim. Acta, 8, 1359-1365 (1993).

11. N. E. Tokel and A. J. Bard, J. Am. Chem. Soc., 94, 2862 (1972).

12. I. Rubinstein, C. R. Martin and A. J. Bard, J. Am. Chem. Soc., 55, 1580 (1983).

13. K. Sasaki, H. Urata, K. Uneyana and S. Nagaura, Electrochim. Acta, 12, 137 (1966).

14. G. Sundholm, J. Electroanal. Chem., 31, 265(1971).

15. H.Hitmi, E. M. Belgsir, J. M. Leger, C. Lamy and R. O. Lezna, Electrochim. Acta, 39, (1994) 407.

16. G. Sundholm, in Encyclopedia of Electrochemistry of the Elements Organic Section (Ed. by A. J. Bard) Vol. 11, p207.

17. H. Karatani and T. Shizuki, Electrochim. Acta, 41, 1667(1996).

18. H. Karatani, J. Photochem. Photobiol. A: Chem., 79, 71 (1994). 